\title{
Assessment of Factors Affecting Youth Intention Towards Entrepreneurship (In the Case of South Gondar Zone, Amhara Region)
}

\author{
Alebel Woretaw Feyisa Debisa Tilahun Lakew \\ Lecturer,Debre Tabor University, Debre Tabor, Ethiopia
}

\begin{abstract}
It is known that Ethiopia has been working to join countries of middle-income economy in the coming decades. Having this in mind, participating youth entrepreneurs in the economy play a great role. Since the general objective of the study is to assess factors affecting youth intention towards entrepreneurship in south Gondar zone selected woredas. The study employed explanatory research design and both qualitative and quantitative type of data was used for the purpose of the study. To collect primary data, structured questionnaire was designed and collected through based on the random selection by using lottery method. Structured questionnaires were distributed to 398 customers, only 329 complete responses were returned from the customers. The SPSS version 20 was use as a tool to process the primary data which is collected through questionnaire. The result of the study indicated that, Only $27.8 \%$ of the variation of dependent variable (youth entrepreneurial intention) can be explained by the five independent variables (Social norm, Perceived access for finance, Perceived government policy, entrepreneurial education $\&$ family background). The overall regression model for these five predictors has significantly explained the variation on youth's entrepreneurial intention. Based on the findings of the study, the researcher gives some recommendations includes significant difference in entrepreneurial intention was found between youths of business family background and non business family background. Non business family background students have lower entrepreneurial intention than business family background students. Therefore, Specific intervention program such as seminars and experience sharing program should be done to improve entrepreneurial intention among non business family students.
\end{abstract}

Keywords: youth intention, Entrepreneurship Education, Perceived Access to finance, Family background, Perceived Government policy \& social norm

DOI: $10.7176 / \mathrm{JESD} / 10-17-02$

Publication date:September $30^{\text {th }} 2019$

\section{Introduction}

Entrepreneurship has been considered as engine of economic progress and job creation and it contributes to economic development in developing countries (Hurry, 2007). It is known that Ethiopia has been working to join countries of middle-income economy in the coming decades. In this process, the problem of young unemployment is gaining series attention in the country (Guarcello et al,2008). Thus, the government of Ethiopia gives due emphasis to employment creation by formulating different policies and strategies. One of these strategies is to promote entrepreneurship. In this sense, entrepreneurship is seen as one of the mechanisms of solving unemployment problems.

The plan for accelerated and sustained development to eliminate absolute poverty from Ethiopia considers self-employment as possible solution of unemployment among youth. Actually, self-employment is the dominant type of employment in the country that employed majority of the labor forces in the country. Despite it composes highest portion of total employment, most Self-employed individuals are illiterate. Self-employed individuals come from the least educated segment of the labor is unlike to get wage offers that would make employment an option, and smaller proportion of the highest educated individuals are moving into self-employment (Getinet ,2005). The public and private sector employment are considered as "Good jobs" while self-employment is considered as "Bad jobs" (Serneels, 2007). This show that highly educated workforce of the country prefer an organizational employment than self-employment. In contrast to this, the government employment policy considers self-employment as viable employment option for youth unemployment. To realize entrepreneurship as viable employment option for youth, the intention of those youths who are too dependent on government and private sectors for employment should be changed.

Entrepreneurship has been considered as a possible solution to address poverty in developing countries specifically in Ethiopia. It is a means of cope up with unemployment problems by providing new job opportunities, and it is also seen as an engine of economic progress and job creation. It has great contribution to economic development of developing countries. Because of this, most of the developing countries are encouraging their citizens to pursue entrepreneurship (Hurry, 2007).

Entrepreneurial intention is said to be an emerging business phenomena so that understanding this intention would help to know the factors that affect youth intention to wards entrepreneurship in south Gondar zone. 


\section{Objective of the study}

General objective

The general objective of the study is to assess factors affecting youth intention towards entrepreneurship.

\section{Specific objectives}

The specific objectives intends:

- To investigate factors that affect youth intention towards entrepreneurship

- To examine the factors that motivates for starting a business a viable alternative for the youth.

- To know influencers for the unemployed youth on the study area

\section{Research Hypothesis}

In addition to the research questions stated above, the following hypotheses are also stated:

H1: Family background has positive and significant influence on youth intention towards entrepreneurship.

H2: Entrepreneurship education has positive and significant influence on youth intention towards entrepreneurship.

H3: Social norm has positive and significant influence on youth intention towards entrepreneurship.

H4: Perceived government policy has positive and significant influence on youth intention towards entrepreneurship.

H5: Perceived Access to finance has positive and significant influence on youth intention towards entrepreneurship.

\section{Conceptual frame-work for the study} Independent variables

\section{Dependent variable}

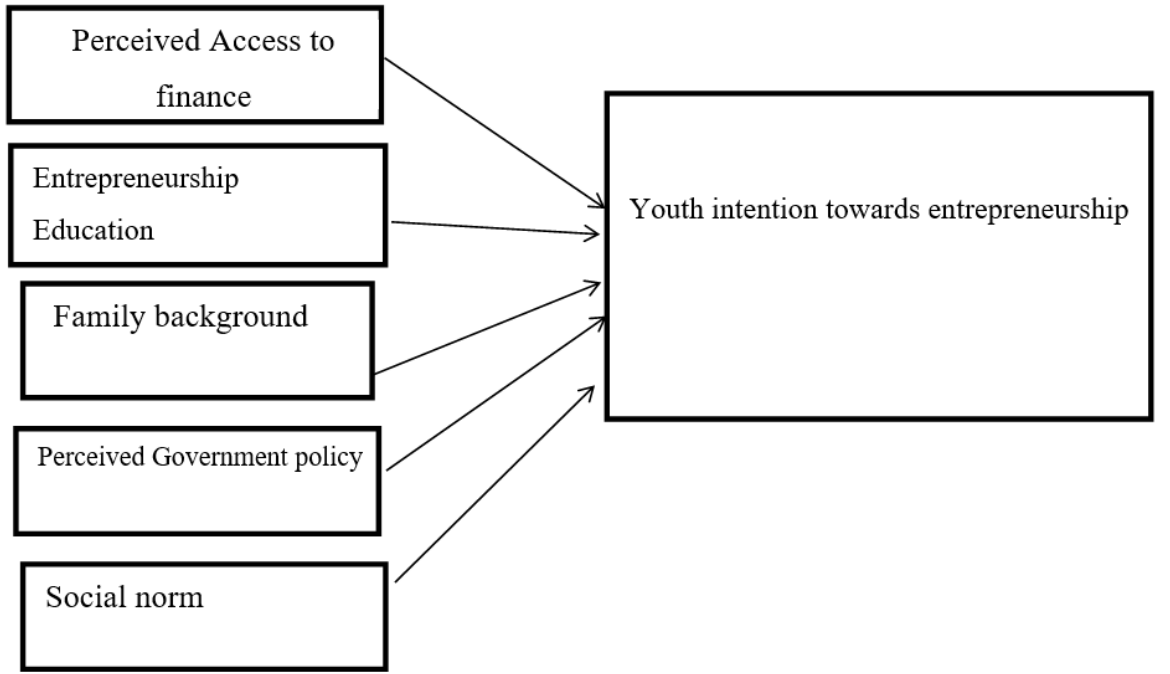

Source: compiled from literature review (2018)

\section{Research Methodology}

This part of the research describes the area of the study, research design, the target population, sampling design, data collection tool and techniques and lastly data analysis employed in the study. 


\section{Description of the Study area}

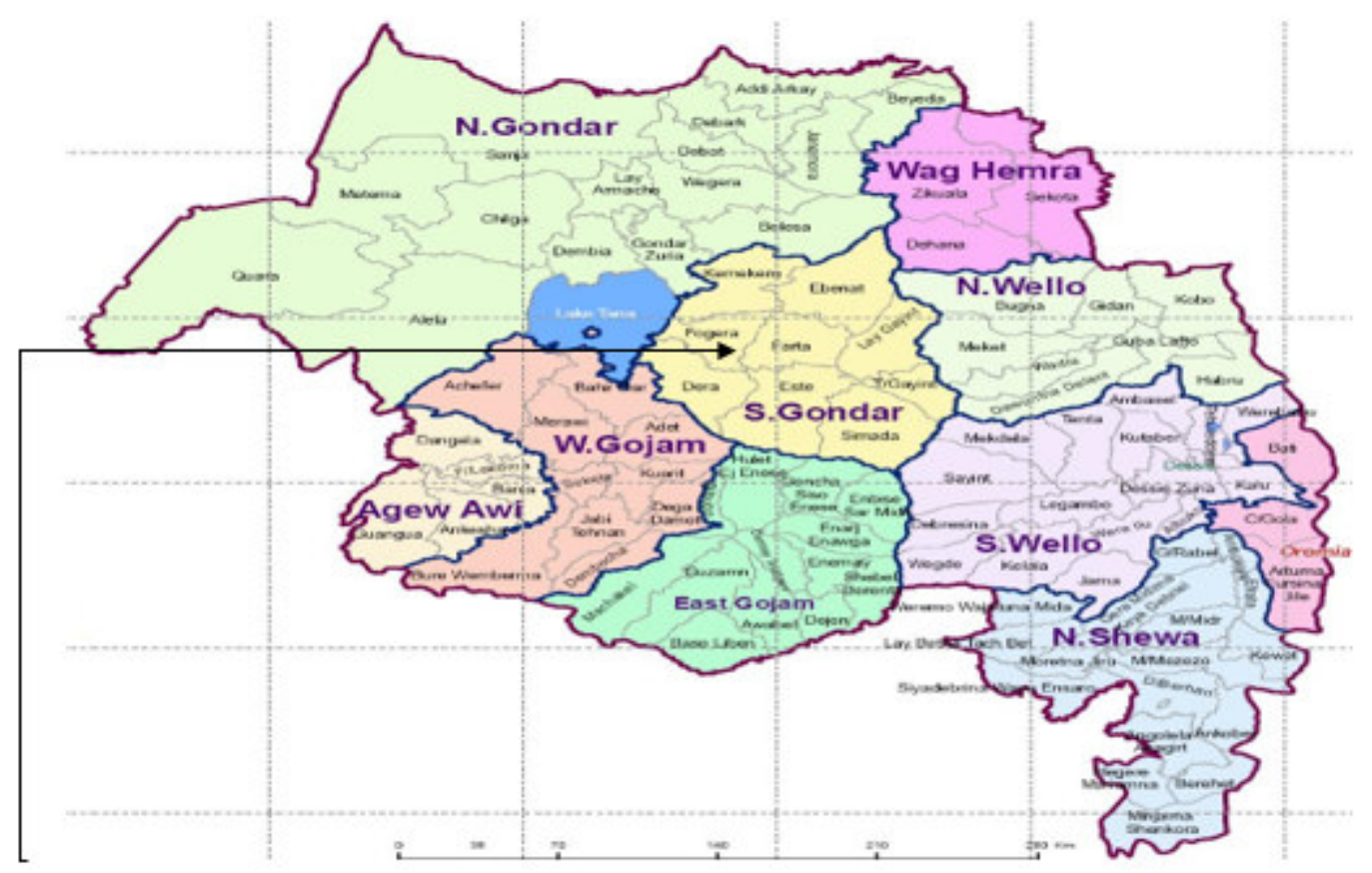

Fig.1.1. Map of the regions/zones of Ethiopia (Source: from Wikipedia, the free encyclopedia).

South Gondar administration Zone is one of the Amhara National Regional State zonal provinces in the Federal Democratic Republic of Ethiopia. South Gondar is bordered on the south by East Gojjam, on the southwest by West Gojjam and Bahir Dar city, on the west by Lake Tana, on the north by North Gondar, on the northeast by Wag Hemra, on the east by North Wollo, and on the southeast by South Wollo; the Abbay river separates South Gondar from the two Gojjam Zones. The area is located at 11" 38'N, 37" 10'E with the total area of a land mass $14298.72 \mathrm{sq} \mathrm{km}$. South Gondar administration includes 10 rural provinces and 5 urban city administrations. And when we see the public sectors administrations and structures there are 28 zonal public offices within each the structure also established at woreda levels. The largest ethnic group reported in South Gondar was the Amhara (99.89\%); all other ethnic groups made up $0.11 \%$ of the population. Amharic is spoken as a first language by 99.92 percent (Zonal Finance Economic Development office plan, 2012).

\section{Demography}

South Gondar Zone administration has a total population of 2,135,834 of this 215,403 urban population (of whom 108,088 are men and 112,500 women) and 2,023,334 rural populations (of whom 987,054 are men and 50,955 are women). And from the total population, $82 \%$ and above have lived in the rural part of the area. The largest ethnic groups in the area were the Amhara (99\%) all other ethnic groups made up $1 \%$ of the population. $90 \%$ of the population practiced Orthodox Christianity $4 \%$ were Muslims, and 1\% others (Zonal Finance Economic Development office plan, 2016).

\section{Research Design}

The study was employed explanatory research design and both qualitative and quantitative research approach was used. The focus of this study was to analyze which factor affecting youth intention towards entrepreneurship in south Gondar zone at selected districts; therefore, descriptive research design is appropriate as it enabled the researcher to generalize the findings to a large population. Explanatory research design is necessary when a researcher encounters an issue that is already known and have a description of it to have critical evaluation of it, not only describe the characteristics, but also it analyzes and explains why and how it happened or is happening.

\section{Target population}

For this research study all unemployed youth currently found in south Gondar zone were included as a target population. The total target population is 104,092 unemployed youth.

\section{Sampling Design}

In south Gondar zone there are 10 rural woredas and five city administrations. The researchers classified these woredas in to five clusters based on their geographical locations. 
From the formed five clusters the researchers selected four rural woredas namely: Simada, Ebinat, Estie, Dera and two city administration: Nefas Mewucha and Debre tabor city administration based on the random selection by using lottery method as given below in the table.

Sampling frame

\begin{tabular}{|c|c|c|c|c|c|}
\hline clusters & Name of clusters & $\begin{array}{l}\text { Woreda selected } \\
\text { from the cluster }\end{array}$ & $\begin{array}{l}\text { Unemployed you } \\
\text { selected Woreda }\end{array}$ & om the & $\begin{array}{l}\text { Sample size } \\
\text { selected }\end{array}$ \\
\hline \multirow{4}{*}{1} & Simada & \multirow{2}{*}{-Simada } & Total populatio & percentage & \multirow{3}{*}{88} \\
\hline & Tach Gaint & & \multirow{2}{*}{9259} & \multirow{2}{*}{22} & \\
\hline & Lay gaint & \multirow{2}{*}{$\begin{array}{l}\text {-Nefas mewucha } \\
\text { town }\end{array}$} & & & \\
\hline & Nefas mewucha & & 1881 & 5 & 19 \\
\hline \multirow{3}{*}{2} & Andabet & \multirow{3}{*}{ - Estie } & \multirow{3}{*}{8301} & \multirow{3}{*}{19} & \multirow{3}{*}{76} \\
\hline & Estie & & & & \\
\hline & Mekane yesus & & & & \\
\hline \multirow{3}{*}{3} & Ebinat & \multirow{3}{*}{-Ebinat } & \multirow{3}{*}{9146} & \multirow{3}{*}{21} & \multirow{3}{*}{83} \\
\hline & Libo kemekem & & & & \\
\hline & Addis zemen & & & & \\
\hline \multirow{4}{*}{4} & Woreta & \multirow{4}{*}{-Dera } & \multirow{4}{*}{8841} & \multirow{4}{*}{20} & \multirow{4}{*}{80} \\
\hline & Dera & & & & \\
\hline & Hamusit & & & & \\
\hline & Fogera & & & & \\
\hline \multirow{3}{*}{5} & Farta & \multirow{2}{*}{-Debre tabor city } & \multirow[b]{2}{*}{5716} & \multirow[t]{2}{*}{13} & \multirow{2}{*}{52} \\
\hline & Debretabor city & & & & \\
\hline & admn & Total & 43144 & 100 & 398 \\
\hline
\end{tabular}

\section{Source: compiled by the researchers (2018)}

The researchers applied the formula below by Yamane (1967) in determining the sample size from a definite population. Therefore, in this study the sample size was determined by using proportional allocation of the four selected woredas and two city administrations.

\section{Sample size determination formula}

The researcher used the formula below in determining the sample size.

$\mathrm{n}=\mathrm{N} / 1+\mathrm{N}(\mathrm{e}) 2$

Where,

$\mathrm{n}=$ sample size, $\mathrm{N}=$ population size, $\mathrm{e}=$ level of precision

Confidence level $=95 \%$ precision $=5 \%$

$104092 / 1+104092(0.05)^{2}=398$

Therefore the sample size for this research was 398 .

\section{Sources and Methods of data collection}

For this research both primary and secondary data sources were employed.

\section{Primary Sources}

Primary data was collected directly from unemployed youth and Enterprise office leaders from each selected woredas and City administration.

\section{Secondary Sources}

Secondary Data from office files and working manuals were used to provide additional information and to make the study fruitful.

\section{Data collection tools and techniques}

For the study well organized questionnaires were utilized to a sample population and interview for leaders.

The questionnaires are administered through drop and pick method and sought to gather information from unemployed youths from each selected woredas and city administration.

\section{Instrument Validity and Reliability test}

Even if questionnaires will be adopted from other sources with little modification, and can be designed based on research questions and objectives, Proper detection by panel of experts in related fields will also be made to ensure 
the face and content validity of the instruments. Finally, the improved version of the questionnaire will be printed, duplicated and dispatched.

An internal consistency reliability test will be conducted using Cronbach's alpha coefficient test for each statement rated on a 5 point likert scale through questionnaire that will be distributed for pilot study

Typically Cronbach's alpha value of 0.70 or higher is taken as a good indication of reliability, although others suggest that it is acceptable if it is 0.67 or above (Cohen et al., 2007).

\section{Methods of Data processing and analysis}

After gathering data it was processed (i.e edited, coded, tabulated) and then analyzed according to the objective of the study. Further transformation of the processed data to look for patterns and relationship between and/or among data groups the analysis was made using descriptive and inferential (Statistical) analysis. The Statistical package for social Science (SPSS) version 20.0 was used to analyze the data obtained from questionnaire. Specifically, descriptive statistics (frequency distribution, percentage) and inferential statistics (Parsons' correlation and linear regression) were also used as a tool.

i. Descriptive Analysis

Descriptive analysis will be used to describe qualitative data obtained from questionnaire and to reduce the data in to a summary format. And the interview questions will be used to analyze the collected data using descriptive narrations.

ii. Inferential Analysis

According to Sekaran (2000) inferential statistics allow inferring data through analysis of the relationship between two or more variables. In this research linear regression and pearsons correlation will be used to see the relationship between Independent variable and Dependent variables.

\section{Data analysis \& presentation}

From our total sample size (398 respondents) distributed questionnaires, we have collected only $\mathbf{3 2 9}$ questionnaires and the data has been analyzed based on those respondents response.

\section{Correlation Analysis between factors and Entrepreneurial intention}

This study was to analyze whether there exist significant relationships between independent variable i.e. (access of finance, social norm, government policy, entrepreneurship education and family background \&) and the dependent variable i.e. (youth entrepreneurial intention). To attain this, Pearson product moment correlation coefficient was calculated and the results are presented in table below.

\section{Summary of Pearson Correlation Coefficient Analysis}

\begin{tabular}{|c|c|c|c|c|c|c|c|}
\hline \multicolumn{8}{|c|}{ Correlations } \\
\hline & & 1 & 2 & 3 & 4 & 5 & 6 \\
\hline \multirow{3}{*}{ Entrepreneurial intention } & Pearson Correlation & 1 & & & & & \\
\hline & Sig. (2-tailed) & & & & & & \\
\hline & $\mathrm{N}$ & 329 & & & & & \\
\hline \multirow{3}{*}{ Social norm } & Pearson Correlation & $.518^{* *}$ & 1 & & & & \\
\hline & Sig. (2-tailed) & .000 & & & & & \\
\hline & $\mathrm{N}$ & 329 & 329 & & & & \\
\hline \multirow{3}{*}{ Perceived access for finance } & Pearson Correlation & $.127^{*}$ & $.261^{* *}$ & 1 & & & \\
\hline & Sig. (2-tailed) & .021 & .000 & & & & \\
\hline & $\mathrm{N}$ & 329 & 329 & 329 & & & \\
\hline \multirow{3}{*}{ Perceived government policy } & Pearson Correlation & $.142^{* *}$ & $.110^{*}$ & $.173^{* *}$ & 1 & & \\
\hline & Sig. (2-tailed) & .010 & .046 & .002 & & & \\
\hline & $\mathrm{N}$ & 329 & 329 & 329 & 329 & & \\
\hline \multirow{3}{*}{ Entrepreneurship education } & Pearson Correlation & -.011 & .039 & $.135^{*}$ & .088 & 1 & \\
\hline & Sig. (2-tailed) & .846 & .478 & .014 & .113 & & \\
\hline & $\mathrm{N}$ & 329 & 329 & 329 & 329 & 329 & \\
\hline \multirow{3}{*}{ Family background } & Pearson Correlation & .024 & .003 & -.019 & .023 & .080 & 1 \\
\hline & Sig. (2-tailed) & .670 & .952 & .738 & .678 & .147 & \\
\hline & $\mathrm{N}$ & 329 & 329 & 329 & 329 & 329 & \\
\hline
\end{tabular}

\section{Source: Survey result, 2018}

In this study, correlation was used to measure the association between entrepreneurial intention and five 
elements (social norm, perceived access for finance, perceived government policy, entrepreneurship education, and family background) on hypotheses $1,2,3,4$ and 5 . The test has been done at $5 \%$ or $1 \%$ significance level.

The result of the correlation in table above shows that the relationship between social norm and entrepreneurial intention is positive $(\mathrm{r}=0.518)$. At the correlation $(\mathrm{r}=0.0 .518)$ and the corresponding $\mathrm{P}$ value $(\mathrm{p}=0.000)$ which less than $(\mathrm{P}<0.01)$ level of significance. Therefore, there is significant positive relationship exist between social norm and entrepreneurial intention at the $(\mathrm{P}<0.01)$ level of significance. This means that there is enough evidence to conclude that pressure exerted from the society determine the entrepreneurial intention in the target areas.

The correlation coefficient between perceived access for finance and entrepreneurial intention is 0.127 with p-value of $0.021<0.05$. Thus, null hypothesis (H0) is rejected. This shows the relationship between perceived access for finance and entrepreneurial intention was slightly positive and significant.

As we can observe from the above table, the correlation coefficient of the perceived government policy and entrepreneurial intention is 0.142 with p-value of 0.010 which is equal to the significant level of 0.01 . This leads to the rejection of the alternative hypothesis. Even though the relationship between perceived government policy and entrepreneurial intention was positive and very weak it was not significant.

As shown in the table of correlation above, the correlation between entrepreneurship education and entrepreneurial intention is negative which is $(\mathrm{r}=-0.011)$. This is a very weak relationship which is approached to zero. The $\mathrm{p}$ value which is $(\mathrm{p}=0.846)$ is greater than acceptable level of significance which is $(\mathrm{p}<0.05)$. So that, there is no significant positive relationship exist between entrepreneurship education and entrepreneurial intention. This means that there is no enough evidence to conclude that entrepreneurship education determines entrepreneurial intention in the study areas.

As we can observe from the above table, the correlation coefficient of the family background and entrepreneurial intention is 0.142 with p-value of 0.024 which is greater than the significant level of 0.05 . This leads to the rejection of the alternative hypothesis. Even though the relationship between family background and entrepreneurial intention was positive \& very weak it was not significant.

\section{Multiple Regression Analysis}

The other intent of this study was to investigate factors affecting youth's entrepreneurial intention i.e., independent variable (social norm, perceived access of finance, and perceived government policy, entrepreneurship education $\&$ family background) on the dependent variable; i.e. youth's entrepreneurial intention in the study areas. It was conducted to investigate the influence of independent variable on the dependent variable and the relative significant influence; the proposed hypotheses were tested using multiple regression analysis. To examine the hypothesis of this research and to know the influence of independent variables and the dependent variable regression analysis were employed and model is shown below.

$$
\mathrm{Y}=\mathrm{b} 0+\mathrm{b} 1 \mathrm{x} 1+\mathrm{b} 2 \times 2+\mathrm{b} 3 \times 3+\mathrm{b} 4 \mathrm{x} 4+\mathrm{b} 5 \times 5
$$

Where: $\mathrm{Y}=$ is dependent variable $\mathrm{b} 0$ is constant $\mathrm{b} 1, \mathrm{~b} 2, \mathrm{~b} 3, \mathrm{~b} 4$ and $\mathrm{b} 5$ are coefficients of each independent variable. $\mathrm{X} 1=$ social norm, $\mathrm{X} 2$ = perceived access of finance, $\mathrm{X} 3=$ perceived government policy, $\mathrm{x} 4=$ entrepreneurship education $\&$ x $5=$ family background.

\section{Multiple regression analysis result}

\begin{tabular}{|l|r|r|r|r|}
\hline Model & \multicolumn{5}{|c|}{ Model Summary } \\
\hline 1 & $.528^{\mathrm{a}}$ & \multicolumn{1}{|c|}{ R Square } & \multicolumn{1}{c|}{ Adjusted R Square } & Std. Error of the Estimate \\
\hline
\end{tabular}

a. Predictors: (Constant), Social norm, Perceived access for finance, Perceived government policy,

Entrepreneurship education, family background

b. Dependent Variable: Youth entrepreneurial intention

Source: survey result, 2018

According to the above table, R Square value for this model is 0.278 . This means that only $27.8 \%$ of the variation of dependent variable (youth entrepreneurial intention) can be explained by the fife independent variables (Social norm, Perceived access for finance, Perceived government policy, entrepreneurial education \& family background) 


\section{Analysis of Variance ANOVA}

\begin{tabular}{|rl|r|r|r|r|r|}
\hline Model & & ANOVA & \multicolumn{1}{c|}{ Sig. } \\
\hline \multirow{2}{*}{1} & Regression & Sum of Squares & df & Mean Square & F & Sig. \\
& Residual & 43.306 & 5 & 8.661 & 24.913 & $.000^{\mathrm{b}}$ \\
& Total & 112.294 & 323 & .348 & & \\
\end{tabular}

a. Dependent Variable: Entrepreneurial intention.

b. Predictors: (Constant), Social norm, Perceived access for finance, Perceived government policy, Entrepreneurship education, family background).

\section{Source: survey result, 2018}

Based on the above table, the $\mathrm{F}$ value is 24.913 with a p-value $0.000<0.00$ significance level. Thus, the overall regression model for these five predictors has significantly explained the variation on youth's entrepreneurial intention.

\section{Regression Coefficients}

\begin{tabular}{|c|c|c|c|c|c|c|}
\hline \multirow[t]{2}{*}{ Mod } & & \multicolumn{2}{|c|}{$\begin{array}{l}\text { Un standardized } \\
\text { Coefficients }\end{array}$} & \multirow{2}{*}{$\begin{array}{c}\text { Standardized } \\
\text { Coefficients } \\
\text { Beta }\end{array}$} & \multirow[t]{2}{*}{$\mathrm{T}$} & \multirow[t]{2}{*}{ Sig. } \\
\hline & & $\mathrm{B}$ & Std. Error & & & \\
\hline \multirow{6}{*}{1} & (Constant) & 1.687 & .351 & & 4.805 & .000 \\
\hline & Social norm & .527 & .050 & .514 & 10.479 & .000 \\
\hline & Perceived access for finance & -.014 & .040 & -.018 & -.355 & .723 \\
\hline & Perceived government policy & .095 & .050 & .092 & 1.898 & .059 \\
\hline & Entrepreneurship education & -.070 & .087 & -.038 & -.800 & .425 \\
\hline & Family background & .047 & .099 & .022 & .474 & .636 \\
\hline
\end{tabular}

a. Dependent Variable: Youth entrepreneurial intention

\section{Source : survey result,2018}

Based on the Table 4.7, the regression equation for the youth entrepreneurial intention (YEI) is:

$\mathrm{YEI}=1.687+0.527 \mathrm{X} 1+(0.014) \mathrm{X} 2+0.095 \mathrm{X} 3+0.047 \mathrm{X} 4$

According to the equation above, social norm, perceived government policy and family background have positive relationship with youth entrepreneurial intention while Perceived access for finance and entrepreneurship education has negative relationship to youth's entrepreneurial intention.

Social norm is the predictor variables that contribute the highest to the variation of the youth entrepreneurial intention; every unit increase in social norm, it will increase a total of 0.527 unit of youth entrepreneurial intention provided other independent variables remain constant. The second highest predictor is perceived government policy $(\beta=0.095)$. Entrepreneurship Education and perceived access for finance has a negative relationship with entrepreneurial intention; every one unit increase in youth entrepreneurship Education, will lead to decrement of entrepreneurial intention by $0.070 \&$ every one unit increase in perceived access for finance will lead to decrement of entrepreneurial intention by 0.014 holding other variables constant.

\section{Conclusion and Recommendation \\ Conclusion}

The study has five main independent variables and one dependent variable. Namely; social norm, perceived access of finance, perceived government policy, entrepreneurship education, family background and youth entrepreneurial intention respectively.

Based on the correlation \& regression analysis results:-

- Pressures exerted from the society determine the entrepreneurial intention in the target areas.

- Perceived access for finance and entrepreneurial intention was slightly positive and significant.

- Only $27.8 \%$ of the variation of dependent variable (youth entrepreneurial intention) can be explained by the five independent variables (Social norm, Perceived access for finance, Perceived government policy, entrepreneurial education \& family background).

- The overall regression model for these five predictors has significantly explained the variation on youth's entrepreneurial intention.

- Perceived access for finance and entrepreneurship education has negative relationship to youth's entrepreneurial intention.

- Social norm is the predictor variables that contribute the highest to the variation of the youth entrepreneurial intention. 


\section{Recommendation}

Based on the finding of the study, the following recommendations are forwarded;

- The significant difference in entrepreneurial intention was found between youths of business family background and non business family background. Non business family background students have lower entrepreneurial intention than business family background students. Therefore, Specific intervention program such as seminars and experience sharing program should be done to improve entrepreneurial intention among non business family students.

- The significant difference in entrepreneurial intention was not found between individuals those attended entrepreneurship course and those did not attend entrepreneurship course. The entrepreneurship education did not make significant difference among students. So that, university should re - assess entrepreneurship course in terms of its content, teaching methods etc, and design effective course that can make significant contribution to entrepreneurial intention of students.

- This study was found that there is positive and significant relationship exists between social norm and youth's entrepreneurial intention. Therefore, the entrepreneurship club should be established as centre of experience sharing in the society at large.

- This study was found that, there is no significant positive relationship exists between perceived access to finance and entrepreneurial intention. Even though, significant positive relationship was not found between perceived access to finance and entrepreneurial intention, the youth's perception towards access to finance for starting new business was found negative. Therefore, work should be done to change this negative perception.

- Policy makers should develop various programs that might build positive image of entrepreneurship in the society.

- Educators should work on career advisor service to promote entrepreneurship as career choice of students.

\section{References}

Ajzen, I. 1991.The theory of planned behavior. Organizational Behavior and Human Decision Processes, 50: 179211.

Bandura, A. (2001). Social cognitive theory: a genetic perspective. Annual Review of Psychology, 52(1)5-30.

Chell E and Allman K(2003), Mapping the motivations and intentions of technology orientated entrepreneurs, R\&D Management Blackwell Publishing Ltd, Oxford, UK.

Crant, J. M. 1996. The proactive personality scale as a predictor of entrepreneurial intentions Journal of Small Business Management: 42-49.

Dawit Eshetu (1999): from bread-winning to money making: individual and social factors behind successful entrepreneurship.

Dyer, W. G. (1994). Toward a theory of entrepreneurial careers: Entrepreneurship Theory and Practice, 17, 7-21.

European Commission (2003) Green Paper on Entrepreneurship in Europe, Brussels: Commission of the European Communities Fleming P. (1994). 